\title{
New record of anchithere (Anchitherium aurelianense) in the Miocene of Eastern Siberia, Russia
}

\begin{abstract}
Alexey M. Klementiev*, Alexander V. Sizov
ABSTRACT. New material on anchithere is described from Miocene of Eastern Siberia (Tagay locality, Olkhon Island, Lake Baikal). Based on the structure of teeth and postcranial bones, the Baikalian record is referred to the widespread Eurasian species Anchitherium aurelianense. This form shows low crowned lophodont type teeth without cement. Metaloph is mostly connected with ectoloph, protoloph does not connect with ectoloph; secondary structures of the anterior wall of metaloph (crochet) are not developed or incipient. The Early Miocene age of the Siberian anchithere is inferred from the archaic skeletal morphology and comparison with European and Asian records.
\end{abstract}

KEY WORDS: Anchitherium, Miocene, Lake Baikal, Olkhon Island, Eastern Siberia.

Alexey M. Klementiev [klem-al@ya.ru], AlexanderV. Sizov [alpinefox@ya.ru] Institute of the Earth Crust of the Russian Academy of Sciences, Siberian Branch, Lermontova str., 128, Irkutsk, 664033, Russia

\section{Новая находка анхитерия (Anchitherium aurelianense) В миоцене Восточной Сибири, Россия}

\begin{abstract}
А.М. Клементьев, А.В. Сизов
РЕЗЮМЕ. В работе приводится описание находки анхитерия из Сибири (Тагайское местонахождение, оз. Байкал, о. Ольхон). На основании подробной характеристики зубов и костей конечностей сибирский анхитерий отнесен к широко распространенной евроазиатской форме Anchitherium aurelianense. Для этой формы характерны брахиодонтные зубы лофодонтного типа, без цемента, металоф примыкает к эктолофу (иногда отделен), протолоф отделен от эктолофа, вторичные структуры (кроше) на передней стороне металофа не развиты или в начальной стадии формирования. На основании архаичных признаков морфологии скелета и сравнения с европейскими и азиатскими формами делается вывод о раннемиоценовом возрасте найденных остатков.
\end{abstract}

КЛЮЧЕВЫЕ СЛОВА: Anchitherium, миоцен, Байкал, Ольхон, Восточная Сибирь.

\section{Introduction}

Forms of the well-known genus Anchitherium Meyer, 1844 were widespread in Eurasia during the Miocene Epoch. In Russia, remains of this genus were found in the Northern Caucasus (Borissiak, 1945; Gabunia, 1973) in the well-known Belomechetskaya locality (Middle Miocene, MN6), extensively cited in the literature (Abusch-Siewert, 1983; Forsten, 1990; Iñigo, 1997; Miyata \& Tomida, 2010, etc.). A less known record of Anchitherium sp. from Tagay locality on the Olkhon Island, Lake Baikal was mentioned by Vera Gromova (Logatchev et al., 1964). Recent excavations at the Tagay section, which started in 2008 (Danilov et al., 2012; Tesakov et al., 2014) provided additional material for further study of this ancient equid.

The locality of Miocene vertebrates Tagay 1 is situated in the Tagay Bay on the western shore of the Olkhon Island (Lake Baikal), south-west of the settlement of Khuzhir. Miocene deposits yielding vertebrate fauna outcrop in the coastal cliff at the north-eastern part of the bay (Logatchev et al., 1964; Mats et al.,
2001). Diverse and relatively abundant large mammal fauna of the Tagay locality is still insufficiently studied. Only Tagay artiodactyls were described in detail (Vislobokova, 1990, 1994). The age of Tagay fauna is estimated by different authors from late Early Miocene, MN4 (Vislobokova, 1994) to late Middle Miocene, MN78 (Daxner-Höck et al., 2013). We currently favour the latest Early Miocene age estimate (Tesakov et al., 2014).

\section{Material and methods}

All materials described below originated from the Miocene deposits of the Tagay 1 locality. Bones of anchitheres were excavated during field seasons of 2011-2015. The material includes a fragmentary maxilla with incomplete tooth rows, mostly fragmentary lower molars, fragmentary and intact postcranial bones. The collection is preserved in the Institute of Earth Crust of the Siberian Branch of the Russian Academy of Sciences (Irkutsk, Russia), collection number IZK79-1.

Morphological description follows the methodology proposed by Stirton (1941), Gromova (1949), 
Abusch-Siewert (1983), and partly Evander (2004). Terminology and abbreviations for measurements are according to Iñigo (1997) and Alberdi \& Rodríguez (2012). For the comparison of dimensions and dental indexes with European forms we additionally used methods and data of and S. Abusch-Siewert (1983). Teeth measurements were taken as maximal values at the crown base. All measurements are in mm. Upper case letters stands for upper teeth, lower case letters, for lower ones (M1, p4).

Scatter diagram was produced by the PAST program version 2.17c (Hammer et al., 2001).

\section{Systematic paleontology}

Order Perissodactyla Owen, 1848

Family Equidae Gray, 1821

Subfamily Anchitheriinae Osborn, 1910

Genus Anchitherium Meyer, 1844

Anchitherium aurelianense (Cuvier, 1825)

Figs $1-3$, Tabs $1-4$.

Hipparion sp. - Ivanjev, 1960: 51.

Anchitherium (?) sp. — Logachev et al., 1964: 42.

MATERIAL: Fragmentary maxilla with P1-P3 dex., P1-P2 sin., and isolated I, C, P3, P4, M1, M2 (12B-1); fragments of P1 dex. $(14 \mathrm{E}-1 / 24)$; incomplete $\mathrm{M} 1-2$ sin. $(14 \mathrm{E}-1 / 1) ; \mathrm{m} 1 / 2$ ? dex. (12D-1/1); incomplete $\mathrm{m} 1 / 2$ ? dex. (four specimens: $14 \mathrm{E}-1 / 2$, $1 / 3,15 \mathrm{~F}-1 / 2,1 / 3)$; incomplete $\mathrm{m} 1 / 2$ ? sin. (14E-1/4); fragments of lower teeth (12A-1/1, and unnumbered specimen); lower m3 dex. (15F-1/1); distal scapula (14F-1); distal fragment of humerus (12D-1/4); distal fragment of radius (14E-1/24); carpal bones (12B-1; 12G-1/2; 14E-1/6-9; 15E-1/3; 15PM); diaphyseal fragments of metacarpals III, MCIII, (11C-1; 14D-1); proximal fragment of MCIII (14E-5); manual phalanx III-2 (12G-1/1); pelvic bone fragment (14E-1/25); fragmentary patella (12A-1/2); distal fragment of tibia (14A-1; 15PM); fragmentary calcanei (14E-1/10, 1/11; 12PM); astragalus (15G-1/ $1)$, fragments of astragali (14E-1/12, 1/13, 1/14; 15G-1/1); small tarsal bones (14E-1/15, 1/16); proximal fragment of MTIII (15E-1/1); fragments of lateral metapodia (12D-1/2; $14 \mathrm{E}-1 / 17,1 / 18,1 / 19)$; incomplete pedal phalanx III-1 (12D$1 / 3)$; fragmentary phalanx III-2 (14E-1/20); first phalanx of lateral toe $(14 \mathrm{E}-1 / 21)$; fragmentary first phalanxes of lateral toes $(14 \mathrm{E}-1 / 22,1 / 23)$.

LOCALITY AND GEOLOGICAL AGE.

Tagay 1, Olkhon Island, Irkutsk Region, Russia. Late Early Miocene, Shanwangian Asian Land Mammal Age, MN5.

\section{DESCRIPTION}

Dental remains.

Fragments of the right and left maxillary tooth rows (Fig. 1A, 1C) of a young adult animal. Permanent teeth completely erupted and show initial stages of wear. The length of the tooth row is 53.7 (P1-P3), and 60.4 (P2P4).

Incisors and canines. The available I3 is damaged. The preserved part of the anterior enamel wall is thicker than the posterior one. Walls completely laterally close the islet. Only the root part is preserved in the canine.

$P 1$. The morphology is typical of early equids, the $\mathrm{P} 1$ is irregularly oval. It has a large crest (ectoloph) and smaller folds on the lingual side, metaloph and rudi- mentary protoloph. Two latter folds restrict the internal valley. The tooth surface behind metaloph is strongly worn. The labial cingulum is lacking, the lingual one is weakly expressed in mesial and distal parts of the crown.

$P 2$. The crown is irregularly pentagonal. The ectoloph has unequal lobes: the anterior one is slightly longer than the posterior. The latter is set obliquely with respect to the long axis of the tooth. Parastyle and metastyle crests on the outer wall of ectoloph are poorly expressed. Parastyle extends at the crown base. It is triangular with a rounded anterior angle. Its cusp is slightly worn and forms a bilobed area (due to the wear of external part of protoloph) connected to a narrow wear zone of the ectoloph. Anterior accessory rib (Evander, 2004) posterior to parastyle is weakly expressed in the upper part of the crown. Paracone is slightly worn. Its connection with parastyle is lower than that with mesostyle. The paracone extends downward and forms a well defined rib on the ectoloph. Anterior lobe of ectoloph extends toward the crown base (from 13.6 to 16.4). Posterior (metaconal) lobe of ectoloph forms a flat surface with a barely noticeable vertical rib (metaconal rib of Evander, 2004) shifted slightly to the posterior edge. Mesostyle is well expressed forming one of the tops of the pentagon. The lingual side of metacone is convex, getting rounded with wear. Small protoconule is widely fused with protocone. In right side P2, there is an accessory cusplet situated in the break between protoloph and parastyle. This elongated cusplet is posteriorly connected with metacone. Its long axis is perpendicular to protoloph. In the left side P2, this cusplet is missing. Hypocone is larger than metaconule, the connection between them are weakly expressed. The crochet is missing. Well expressed crescent hypostyle is separated from ectoloph and hypocone. In the right P2 it has a separate external cusplet of hypoconule (after Evander, 2004). Cingulum is weakly manifested at the lower side of metacone, and also borders anterior, middle, and posterior valley at advanced wear stages. Mesial cingulum bears a small accessory cusplet.

$P 3$. The crown has a rhomboidal shape. The ectoloph has two unequal lobes. The anterior one shows a rounded metaconal rib, whereas the posterior lobe is smooth. Parastyle and mesostyle are strong and pointed, metastyle is less pronounced. Paracone and metacone are strongly convex lingually, being triangular with little wear. Parastyle is large and does connect with protocone. Transverse ridges (proto- and metaloph) of uniform structure are equally developed. Protoloph bears a well defined protoconule. Protocone is higher than protoconule; the protoloph lowers anterolingually and is lower than paracone. The posterior ridge (metaloph) has a small middle bulge (metaconule) which is not expressed at early wear stages. Hypocone nearly equals in size to protocone. It is separated from hypostyle at early wear stages but can connect with it with more wear. The posterior valley is open. Crochet is lacking. Cingulum is well developed along ectoloph, and at mesial and distal sides of the crown, but only 

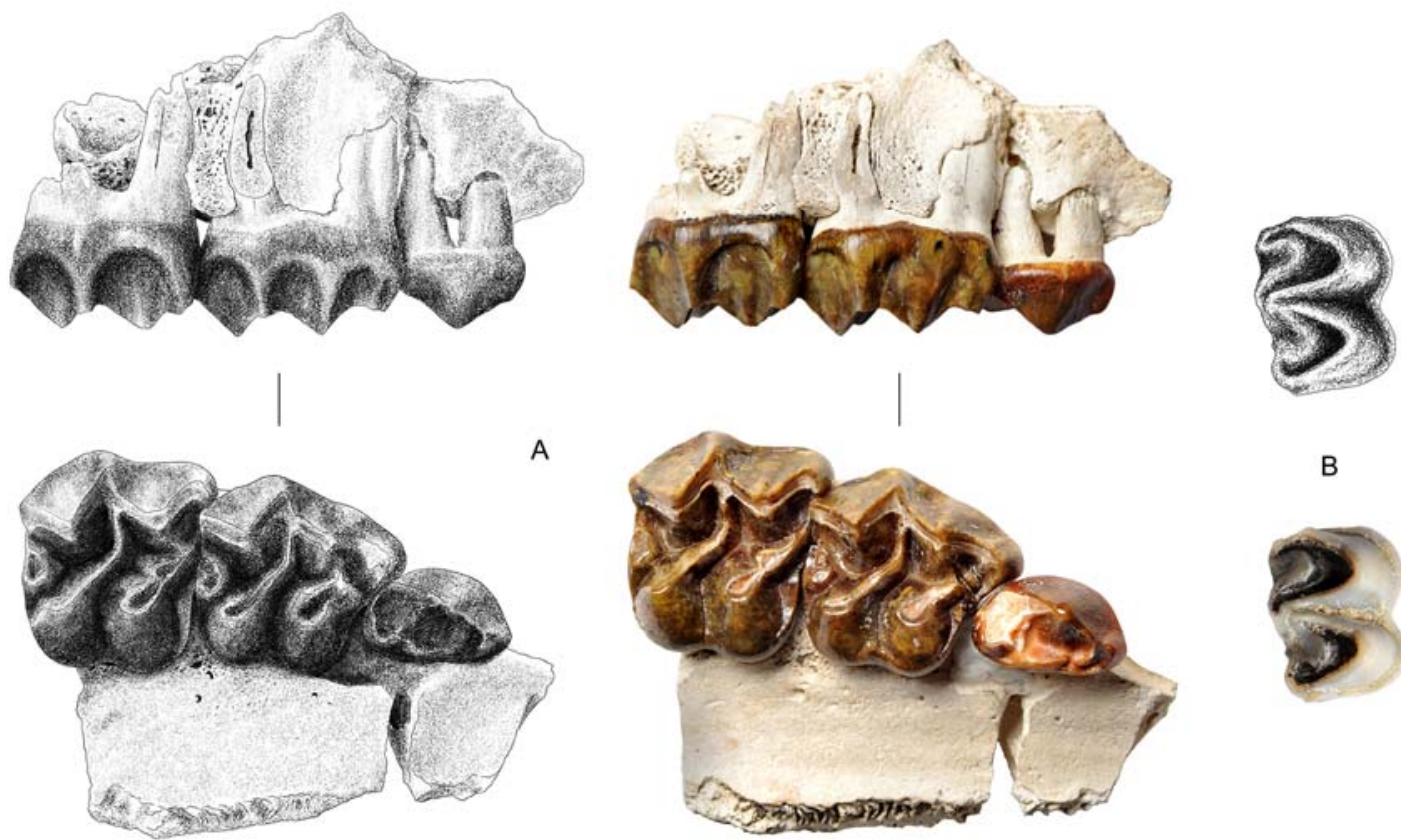

A

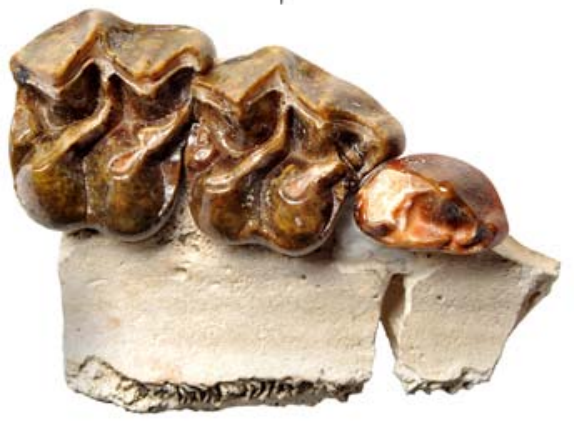

B
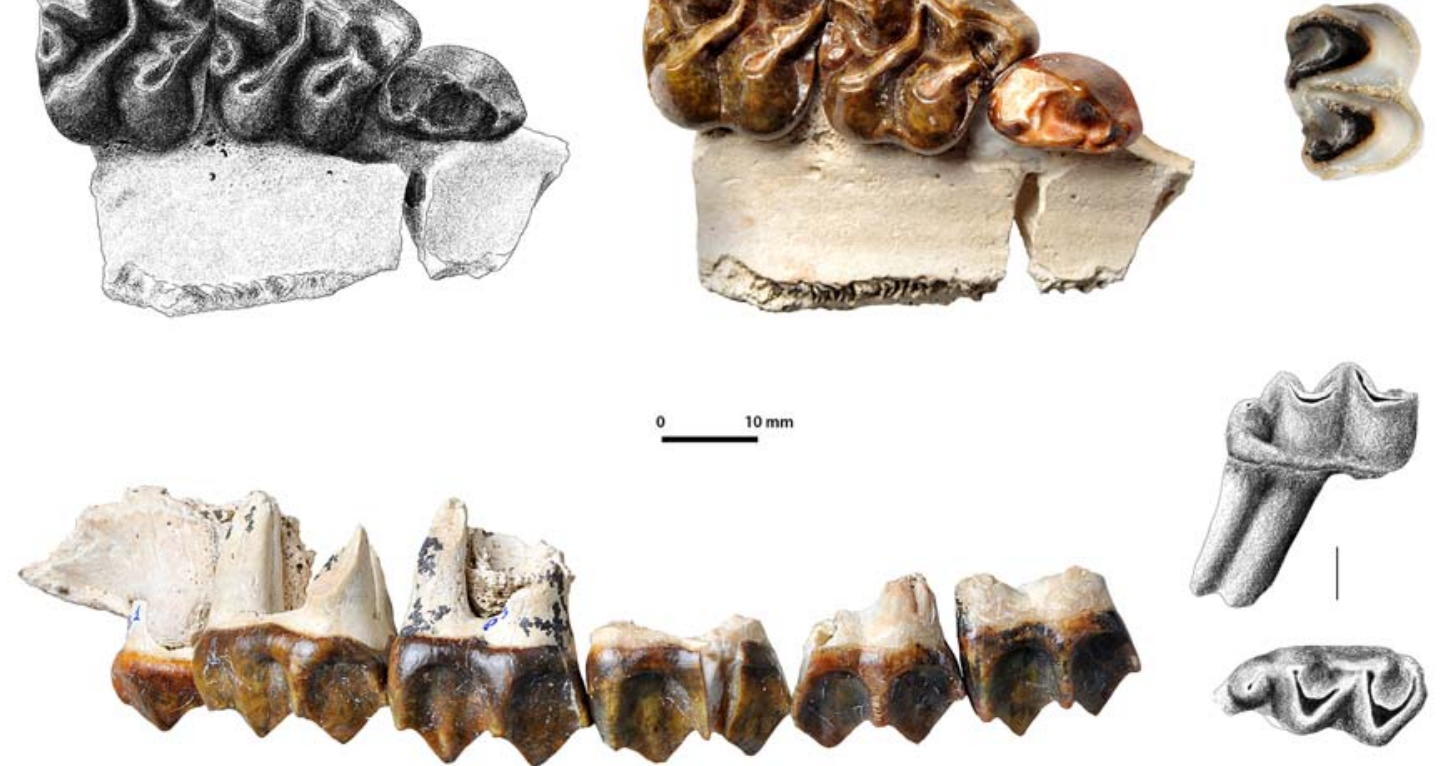

C
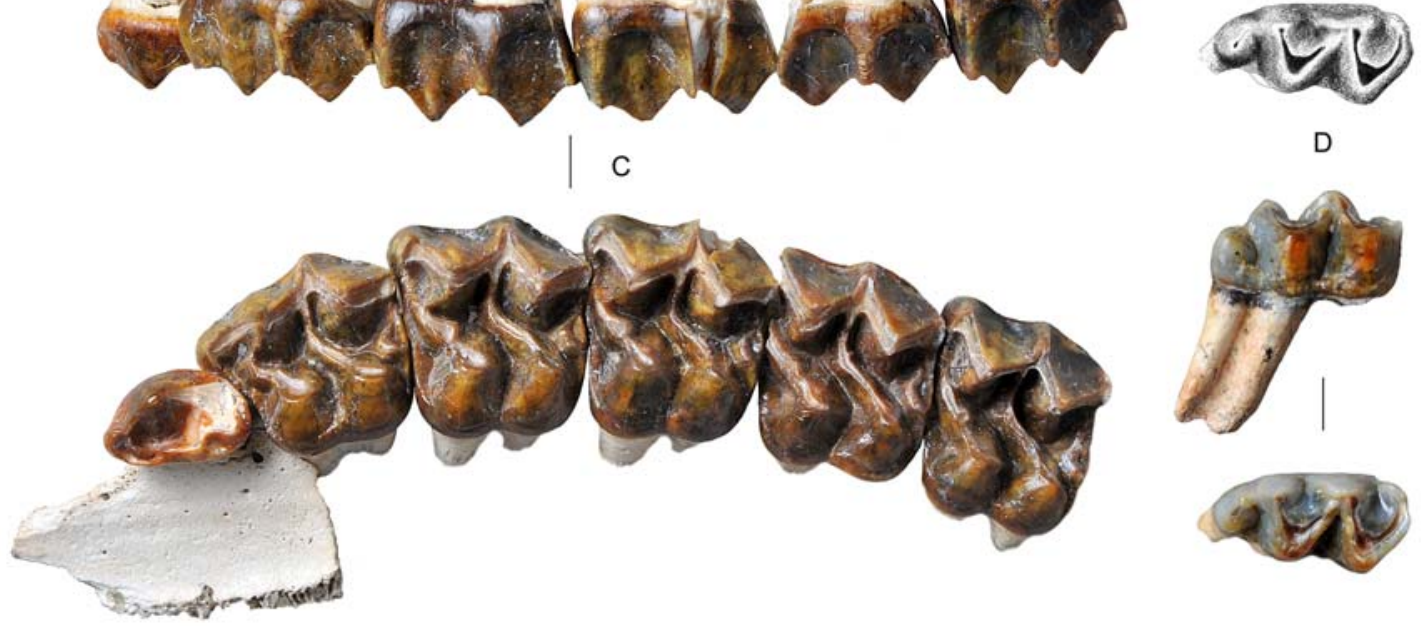

D

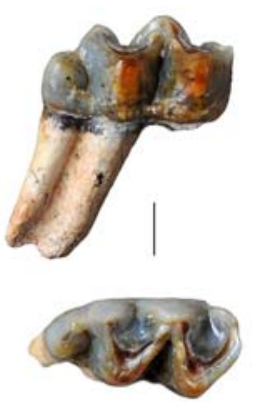

Fig. 1. Anchitherium aurelianense (Cuvier, 1825), Tagay locality, late Early Miocene, dental remains: A - fragment of maxillary tooth row with P1-P3 dex. (labial and occlusial views); B - lower m1-2? dex. (occlusial view); C - left tooth row with P1-M2 (restored); D - lower m3 dex. (labial and occlusal views).

slightly expressed at the entrance to of the middle valley.

P4. Tooth is wider and shorter than P3 and has a trapezoidal shape with labial side slightly longer than the lingual one. Metaloph and hypostyle are unworn.
Lobes of ectoloph are of equal size and meet at an obtuse angle. The outer side of paracone is smooth with a poorly expressed paraconal rib. The outer side of metacone it flatter, the metaconal rib is very weakly developed. Para- and mesostyle are sharp and strong, 
metastyle is less developed. The inner crests of the ectoloph meet at nearly right angle at early wear stage, and it gets more rounded toward the base. Protoloph is shorter than metaloph. Metaloph shows an S-shaped curve due to the connection to ectoloph. The protoloph has a beaded wear structure due to facets of protocone and protoconule. Protocone is large, massive, and postero-lingually inflicted. Pear-shaped protoconule is located posterior to protocone in the middle of the crown. Protoloph does not reach parastyle, but has a thin connection with internal rib of paracone. Protocone is high but lower than paracone. The metaloph is not worn, thus hypocone is higher than protocone in lingual aspect. Metaconule is narrow and also lower than hypocone. Crochet is lacking. A connection of hypocone and hypostyle is weakly expressed. Hypostyle is well defined and has a narrow cingular connection with metastyle. Cingulum is strong mesially, less developed distally and externally, and missing at the mouth of the middle valley.

M1 and M2 are very similar in structure. M1 is more worn than only incipiently worn M2. M1 has a damaged parastyle area. M1-2 are described collectively. Anterior and posterior lobes of ectoloph are equal in size. Para- and mesostyles protrude well, metastyle is less developed. Additional ribs of para- and metacone are only slightly expressed. Protoloph does not connect to parastyle. Protocone is much larger than protoconule. Metaloph is similar in structure to that of premolars. Crochet is lacking or represented by very weak, undeveloped precursors. Metaconule is narrow, placed next to a large hypocone and is connected with ectoloph. Hypostyle is large and mono-lobed. Cingulum is developed similarly to P4. It is strong anteriorly (forming a "shelf" between protocone and protoconule), less developed externally and distally, and represented by weak enamel swelling at the mouth of the middle valley.

Lower m1/2 dex (Fig. 1B). Crown is low, moderately worn $(8.4 \mathrm{~mm})$. Dimensions: length is 18.3 , width, 14.0 , the width index $75.96 \%$. Proto- and hypoconid protrude labially as rounded angles. The external valley is narrow and deep. Metastylid and metaconid are separated, the former is lower than the latter. Internal valleys are shallow and delimited by para- and entoconid. Entoconid is wide, round, protrudes mesially. Paraconid is narrow, curves distally (according to Belyaeva, 1954, it is a curved lingual portion of paralophid). Hypoconulid as enamel rib at the distal wall, appears as an extension of cingulum. Cingulum is well expressed on posterior and external sides of hypoconid, and on the antero-labial side of protoconid. Fragmentary remains (five specimens) show additional characters. A premolar (height, 8.5) has a well developed labial cingulum. Slightly worn molar (height, 9.4; anterior width, 10.9) shows poorly developed labial cingulum and an undivided cusp of metaconid and metastylid. Two fragmentary molars with preserved posterior parts show variable structure. One of these molars has a pronounced hypoconulid and a thickening of cingulum at the outer valley, whereas the other has no cingulum and poorly developed hypoconulid.

Lower $m 3$ dex (Fig. 1D). A small molar $(19.8 \times$ 10.2) at initial wear stage (height, 8.1). Slightly pointed hypo- and protoconid delimit open labial valley. Metaconid-metastylid column has an undivided cusp. Mesio-labial cingulum is well developed. Lingual cingulum is poorly expressed but forms a shelf between hypoconid and large (length, 3.7) talonid (= hypoconulid).

The tooth row characters may be summarized as follows. Premolars P2-P4 are larger than molars. From $\mathrm{P} 2$ to $\mathrm{M} 2$ it is observed, first, separation of protoconule from protocone (P2-P3) and then its size reduction in molars; decreasing asymmetry of ectoloph anterior and posterior parts; decreasing expression of para- and metaconal ribs; width reduction of protoconule; curving and decreasing width of metaconule and coordinated reduction of its connection with ectoloph; decrease (P2-P3) and disappearance (molars) of cingulum at the mouth of the middle valley. Teeth also show the genus-rank common features of Anchitherium: the lack of cement and crochet, separation of hypostyle and ectoloph. Protocone is larger than protoconule and hypocone larger than metaconule. Parastyle does not form a fold. Cingulum is only clearly manifested at the anterior and labial side of all teeth. Premolars differ from molars in better expression of labial ribs of ectoloph. A set of relatively primitive characters of the Tagay anchithere includes low crowned teeth, lack of anterostyle, disconnected ectoloph and protoloph, small protoconule, connection of metaloph and ectoloph, lack of crochet, simple hypostyle, and weakly developed cingulum. Archaic characters of lower teeth include only slightly manifested hypoconulid, weak external cingulum, and divided metaconid-metastylid column.

Postcranial remains.

The pectoral girdle bones are best represented by a well-preserved fragment of the scapula (Fig. 2A) and distal bones. Articular portion of scapula has a hyppoid structure with a deep joint, a large, massive and downturned coracoid process; beak-shaped protrusion is damaged, but appears well developed. Antero-posterior diameter of the articular surface is 35.8 , its incomplete width is 28.3 , the maximal diameter (including caracoid process) of the lower portion of the blade, 54.5. Carpal bones in the material include semilunar ( 2 specimens), trapezoid (3 specimens), and magnum. Dimensions are given in Table 1. Naviculare is not large (anterior width, 15.7; anterior height, 19.2). Upper and lower facets are large, posterior side is not preserved. Semilunar bones (Fig. 2D) have a hyppoid structure with the upper facet for radius and two distal facets for lower carpals, magnum and unciform. The bone has medial facets for articulation with the navicular and two lateral facets for pyramidale. Magnum is flattened. Its upper surface bears facets for navicular and semilunar bones. The posterior edge of the upper surface is shaped as a protrusion (head). Its surface is mainly formed by 

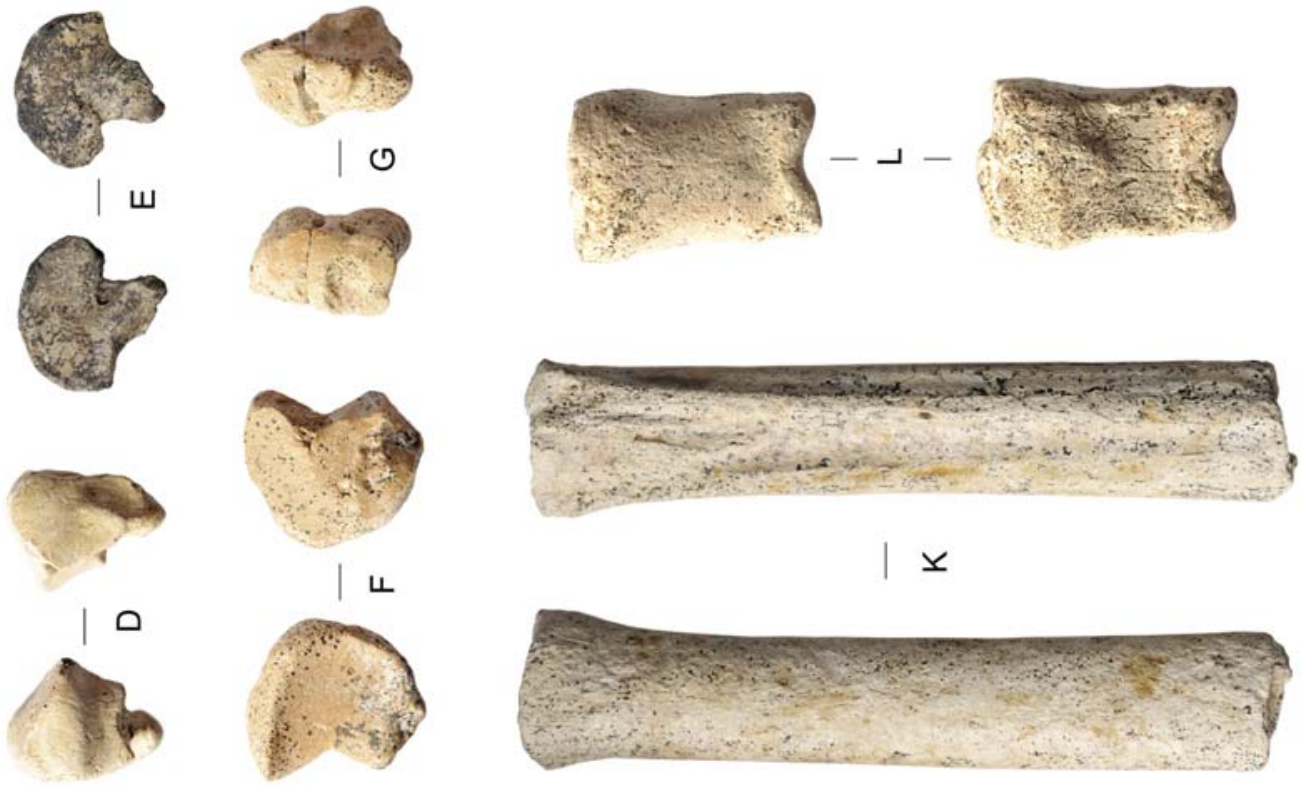

山

$\check{Y}$
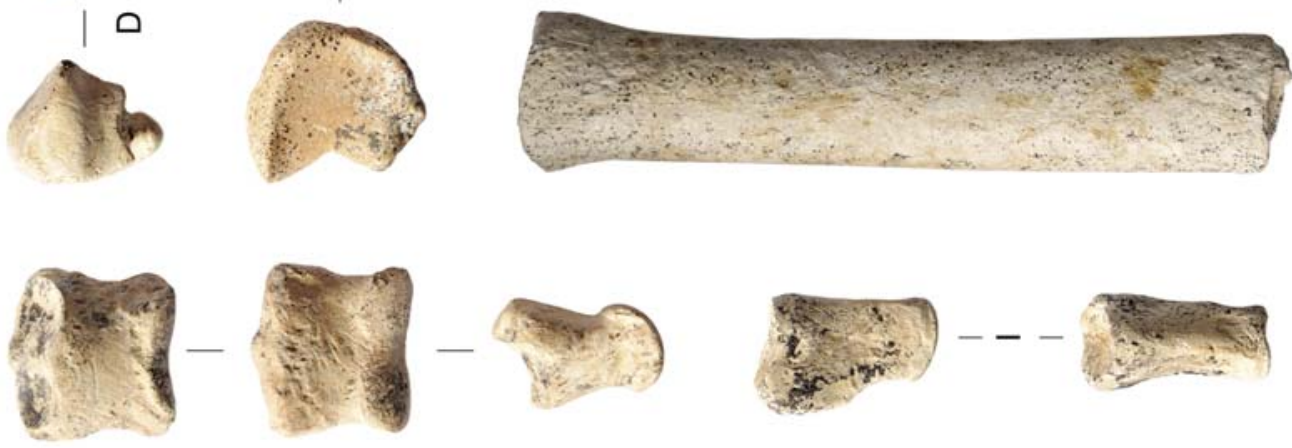

U

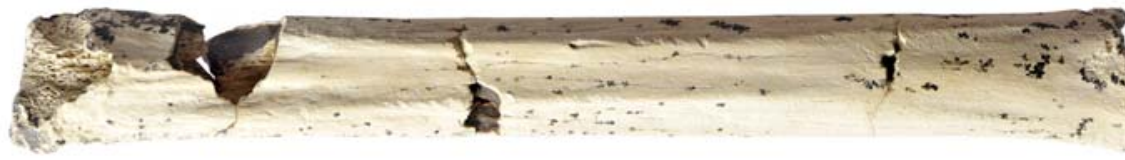

$\infty$
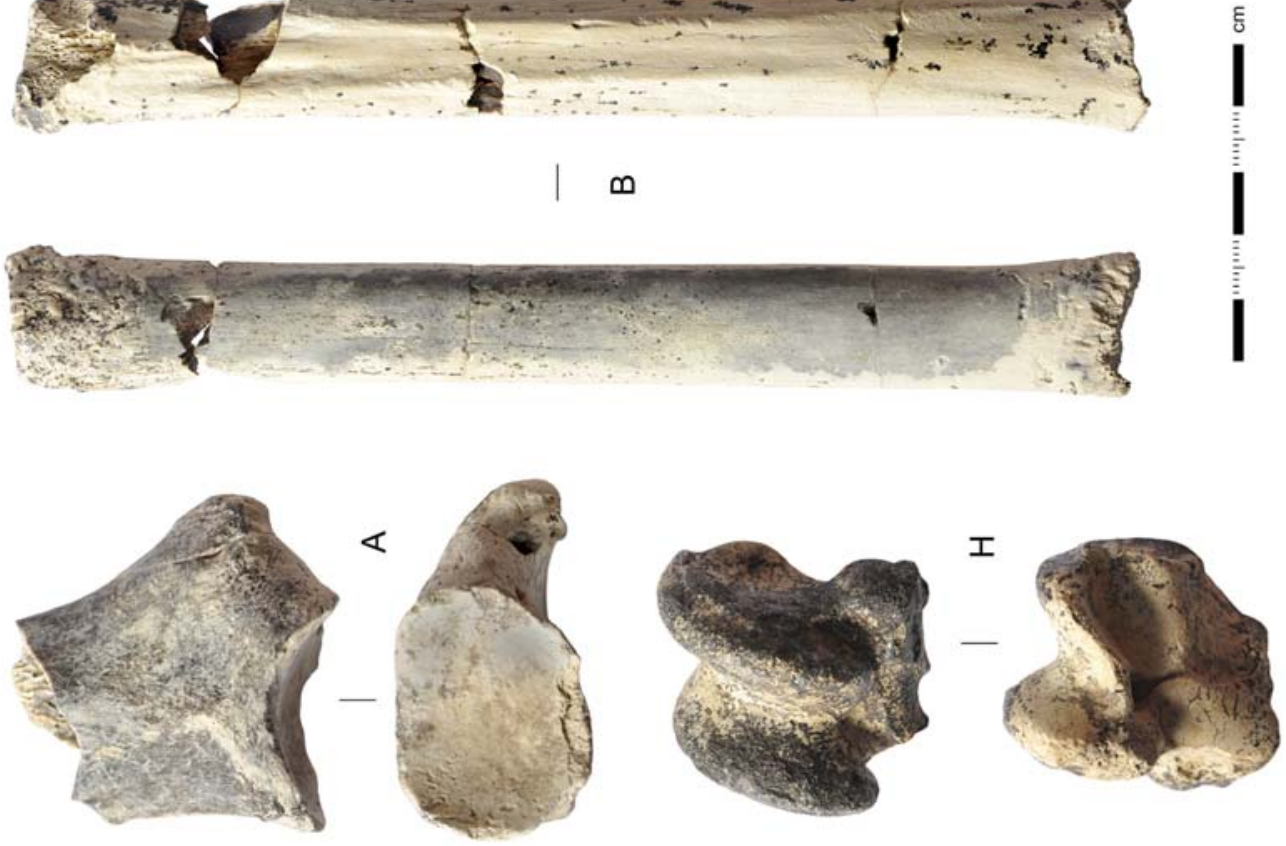

Fig. 2. Anchitherium aurelianense (Cuvier, 1825) Tagay locality, late Early Miocene, appendicular bones: A — distal fragment of scapula dex. (lateral and distal views); B - metacarpal III sin. (dorsal and plantar view); C - manual phalanx III2 dex. (dorsal, plantar, and medial views); D - semilunare dex. (proximal and distal views); E - cuneiform III dex. (views of proximal and distal articulation facets); F - naviculare sin. (views of proximal and distal articulation facets); $\mathrm{G}$ - cuboid dex. (proximal and distal views); H — astragal dex. (frontal and caudal views); I — first phalanx of lateral digit (medial and dorsal view). K — partial MTIII dex. (dorsal and plantar views); L — pedal phalanx III-1 sin. (dorsal and plantar views). 
Table 1. Dimensions of upper teeth of Anchitheriinae.

\begin{tabular}{|c|c|c|c|c|c|c|c|c|}
\hline \multirow{3}{*}{ Localities } & \multicolumn{4}{|c|}{ Anchitherium aurelianens } & \multirow{2}{*}{\multicolumn{2}{|c|}{$\begin{array}{c}\begin{array}{c}\text { Paranchitherium } \\
\text { karpinskii }\end{array} \\
\text { Belomechetskaya }\end{array}$}} & \multicolumn{2}{|c|}{$\begin{array}{c}\text { Anchitherium gobiense, } \\
\text { Anchitherium aff. } \\
\text { gobiense }\end{array}$} \\
\hline & \multirow[b]{2}{*}{ Tagay } & Córcoles & Baigneaux & Sansan & & & $\begin{array}{l}\text { China, } \\
\text { Tung-Gur }\end{array}$ & $\begin{array}{c}\text { Japan, } \\
\text { Hasegawa }\end{array}$ \\
\hline & & $\begin{array}{l}\text { (Iñigo, } \\
1997)\end{array}$ & \multicolumn{2}{|c|}{$\begin{array}{c}\text { (Abusch-Siewert, 1983, } \\
\text { Alberdi \& Rodriguez, 2012) }\end{array}$} & \multicolumn{2}{|c|}{ (Borissiak, 1945) } & $\begin{array}{l}\text { (Colbert, } \\
\text { 1939) }\end{array}$ & $\begin{array}{c}\text { (Miyata \& } \\
\text { Tomida, } \\
\text { 2010) }\end{array}$ \\
\hline Length P1-3/ & 53.7 & & & & & & & \\
\hline Length P1-4/ & 70.8 & & $63.4-64.5$ & $69.0-72.5$ & & & 79 & \\
\hline Length P2-4/ & 60.4 & $65.1-70.8$ & $55.3-56.4$ & $58.5-64.5$ & & & & \\
\hline Length P2-3/ & 41.3 & & & & & & & \\
\hline Length P1/ & 15.9 & $10.9-15.9$ & $12.2-13.0$ & $13.4-14.1$ & & 17 & 16.5 & \\
\hline Width P1/ & 10.2 & $8.4-10.5$ & $8.0-8.7$ & ?9.4-10.6 & & 10 & 11 & \\
\hline Length P2/ & 22.5 & $23.5-26.9$ & $20.0-23.0$ & $20.6-24.1$ & 28 & 29 & 21 & 25.3 \\
\hline Width P2/ & 21.1 & $21.6-25.8$ & $18.3-22.4$ & $20.4-22.9$ & & 27 & 25.5 & 25.0 \\
\hline Length P3/ & 20.7 & $20.6-23.2$ & $18.5-20.5$ & $19.8-21.5$ & & 24 & 21 & 23.9 \\
\hline Width P3/ & 23.4 & $25.5-29.2$ & $21.1-24.0$ & $22.5-25.5$ & & 30 & 27 & 29.2 \\
\hline Length P4/ & 20.0 & $20.6-23.2$ & $19.1-21.1$ & $19.8-23.0$ & 26 & 24 & 22 & 24.5 \\
\hline Width P4/ & 23.9 & $25.5-29.2$ & $22.6-24.7$ & $24.6-26.2$ & 30 & 32 & 28.5 & 29.4 \\
\hline Length M1/ & ca.18.3 & $20.2-24.7$ & $18.0 ; 19.4$ & $20.1-21.7$ & 26 & 23.5 & 21 & 23.6 \\
\hline Width M1/ & 22.5 & $25.0-28.3$ & $21.7 ; 23.6$ & $24.5-26.0$ & 29.5 & 31.5 & 28 & 27.5 \\
\hline Length M2/ & 18.4 & $19.3-22.1$ & $18.4-19.1$ & $19.0-21.6$ & & 24 & 20 & 22.0 \\
\hline Width M2/ & 22.6 & $25.6-28.7$ & $21.7-23.0$ & $23.3-? 26.4$ & & 31 & 28 & 27.2 \\
\hline
\end{tabular}

Table 2. Comparison of dimentions of carpal and tarsal bones of Anchitherium aurelianense from Sansan (Alberdi \& Rodríguez, 2012) and Tagay.

\begin{tabular}{|c|c|c|c|c|c|}
\hline Carpal & Locality & $\mathrm{H}$ & DT & DAP & df-MCII \\
\hline \multirow{2}{*}{ Lunatum } & Tagay & $23.2 ; 21.6$ & & 20.1 & \\
\hline & Sansan & $18.8-26.0$ & & $17.3-21.8$ & \\
\hline \multirow{2}{*}{ Trapezoid } & Tagay & $12.4 ; 11.8 ; 10.2$ & & $13.6 ; 15.7 ; 14.7$ & \\
\hline & Sansan & $13.0-13.7$ & & (12)-14.5 & \\
\hline \multirow{2}{*}{ Magnum } & Tagay & $13.8 ; 13.6$ & $23.3 ; 22.7$ & $26.0 ; 24.1$ & $3.9 ; 4.9$ \\
\hline & Sansan & $12.0-15.0$ & $23.5-27.1$ & $20.3-24.3$ & $2.0-4.6$ \\
\hline Tarsal & Locality & $\mathrm{H}$ & DT & DAP & I \\
\hline \multirow{2}{*}{ Navicular } & Tagay & 9.1 & 27.1 & 26.3 & \\
\hline & Sansan & $9.0-11.0$ & $22.2-30.0$ & $29.8-37.0$ & \\
\hline \multirow{2}{*}{ Cuboide } & Tagay & 20.4 & & 23.1 & \\
\hline & Sansan & $20.9-24.0$ & & $27.5-30.8$ & \\
\hline \multirow{2}{*}{ Cuneiform III } & Tagay & 7.1 & & 20.8 & 25.1 \\
\hline & Sansan & $7.5-10.0$ & & $19.0-24.5$ & $28.0-32.6$ \\
\hline
\end{tabular}

the facet for semilunare and a smaller medial facet for naviculare. Two facets of the inner side for trapezoideum are merged in one specimen and separated in another. Below there is a small facet for metacarpal II. The trapezoidal bone shows a relatively simple structure with the flat lower subtriangular facet for metacarpal II, and the upper trochlear-like facet, which transfers to the posterior surface. Measurements of the third metacarpal bone (Fig. 2B) are given in Table 2. The volar side of the diaphysis forms an area bounded by the rounded ridges. In a proximal fragment of metacarpal III this area forms a swelling below the upper joint. In the distal third of the volar side of diaphysis the ridges disappear and the area becomes convex. The angle between the facets for the magnum and unciform is 63 and 67 degrees. The second phalanx (Fig. 2C) was attributed to the forelimb, based on criteria developed by Kovalevsky $(1873,1948)$. The tuberosity for the attachment of lateral volar ligaments is well developed slightly below the upper joint. The upper joint surface is at 57 degrees to the long axis of the bone. The anterior (dorsal) surface bears no depression, small lower ligamental pits and ridges are clearly visible.

Bones of the pelvic girdle are incompletely preserved. Tubular and pelvic bones are fragmentary. Distal fragments of tibia belonged to young individuals. Of the four specimens of astragalus, two are well preserved (Fig. 2H). It has characteristic features of the 
hyppoid type: tibial trochlea narrow and high; sustentacular facet strongly protruding distally; a small subtriangular facet for the lower part of the external astragalus facet of calcaneum (lower part of ectal facet); a strong projection of the lower joint; well-developed muscular medial tubercle; lack of posterior lower curving of the inner ridge. Distal side of the medial ridge of tibial trochlea connects with lower articular surface (navicular facet). The development of cuboid facets is not preserved in our material. Archaic features, and, include a strongly skewed tibial articulation measured as an angle $\left(22^{\circ}\right)$ between the axis parallel to trochlea ridges and the medio-lateral axis of navicular facet (Kovalevsky, 1873: 41), and stronger lowering of the external ridge compared to the inner one (Gromova, 1949: 52). Dimensions are moderate (Table 2). Fragmentary remains of two calcanei came from the section and one specimen was found on the beach below the section. The bone shows a well developed upper ectal facet. Navicular has a typical hyppoid structure (Fig. $2 \mathrm{~F})$. The upper surface is concave and bears a single facet. The posterior notch of the bone affects only this facet whereas the corpus of the bone bears a projection below. The external side shows two cuboid facets with the anterior one being very small and hardly discernible and the posterior one being large. The lower surface bears four articulation facets for three fused cuneiforms and a cuboid. The anterior width and the anteriorposterior diameter of this bone are 27.1 and 26.3. Cuboid (Fig. 2G) has a series of facets. The upper surface is saddle-shaped convex and bears calcaneal and astragalar facets. Lower facet is pear-shaped, its anterior part is wider than posterior one. The medial surface bears anterior lower facet for metatarsal III, and a flat area marks anterior upper facet for naviculare. The ligamental posterior tuberosity is well manifested. Medial protrusion carries two facets, meeting each other at an angle of $40^{\circ}$. Cuneiform III (Fig. 2E) is not large (Table 2 ). It has a series of facets for neighbouring tarsal bones with largest being that for naviculare and metatarsal III. Medial concavity for the contact with cuneiform II bears four facets. The lateral side has a facet for cuboid.

Proximal portion of the metatarsal III (Fig. 2K) bears a large facet for cuneiform III and much smaller facets for cuneiform II, cuboideum, and metatarsal IV. The posterior part of the diaphysis bears a groove restricted by ridges. This groove transforms into a rough area below the upper joint. Fragmentary first phalanx refers to the short type of Kovalevsky (1873). It is thus defined as belonging to hind limb (Fig. 2L). The bone tapers distally. The groove at the anterior margin of upper joint is missing. Rough triangular elevated area on the upper part of the plantar surface is well defined with its apex reaching the mid length of the bone. Distal lateral ligamentous depressions are missing, epiarticular ridges are weakly expressed. The posterior (plantar) surface bares lateral tubercles for the attachment of lateral ligaments. Distal fragments of lateral metapodia and first lateral phalanges could not be attributed to either fore- or hind limb. Measurements for a complete first lateral phalanx (Fig. 2I) are given in Table 2.

\section{Discussion}

Comparison with remains of anchitheres from $\mathrm{Eu}-$ rope and Asia (Forsten, 1991) is hampered by the limited material. The available literature was used for the comparisons. Nearly all dental characters of the Tagay equid fit the diagnosis of the genus Anchitherium proposed by Gromova (1952: 87-88). The distinction is probably in poorly developed interstylar ribs on ectoloph, though this character is defined by Gromova as "ribs between styles are more or less clearly expressed". The species diagnosis for A. aurelianense by S.Abusch-Siewert (Abusch-Siewert, 1983: 42) is relatively broad and comprises all characters of the Siberian anchithere. In comparisons we tried to use teeth of equal wear stages. Additional materials, when available, will enable more detailed comparisons.

Anchitheres from the Astaracian sites of Turkey (Forsten, 1990) shows P2, which is similar to the Baikal form in the presence of cingulum, metaloph connected with ectoloph, developed hypostyle. Tagay forms is distinct in lacking protoloph-paracone connection and in the lacking of the crochet. P3-M2 in Turkish form were not separated in the description. They are similar to P2 and only differ in the lacking lingual cingulum and crochet. According to Forsten (1990), European samples of $A$. a. aurelianense from Baigneaux (MN4B) and later A. a. hippoides (Lartet) (La Grive, Sansan, MN6-8) show in P2 a protoloph connected with paracone via its high anterior part or by the parastyle fold. This connection and parastyle fold are not present in the Tagay material. The presence, expression and localization of cingulum is variable in European anchitheres from different localities (Abusch-Siewert, 1983) with the frequency of continuous cingulum increasing in later forms (Sansan, Steinheim). In Tagay, the poorly developed cingulum is similar to Late Oligocene-Early Miocene North American Kalobatippus prestans (Osborn, 1918) and K. clarencei (Bryant, 2001). MacFadden (1998) considers the genus Kalobatippus Osborn, 1915 as a tentative younger synonym of Anchitherium. Three subspecies of $A$. aurelianense recognized for the western Eurasia (Abusch-Siewert, 1983; Alberdi et al., 2004) were considered for the comparison. The Tagay anchithere dentally differs from $A$. a. aurelianense in undifferentiated protoconule, short protoloph, undeveloped inner cingulum, short parastyle fold; from A. a. steinheimense, in smaller size, large hypostyle, undeveloped inner cingulum, missing crochet; from A. a. hippoides, in smaller size, undifferentiated protoconule, short protoloph, undeveloped inner cingulum, missing crochet. Due to low crown heights of the Tagay form its height indices (as defined by Abusch-Siewert, 1983) calculated for upper teeth show relatively low values: P2 - HIL 41, HIB 43, HIF 2.0, HIH 111.5; P3/ 4 - HIL 48, HIB 40.5, HIF 2.0, HIH 109 \& 103; M1/ 
Table 3. Comparison of bone dimensions in Anchitherium from Europe (Iñigo, 1997, Córcoles, Alberdi \& Rodríguez, 2012, La Romieu, Baigneaux, Sansan) and Tagay.

\begin{tabular}{|c|c|c|c|c|c|c|c|c|}
\hline Ossa & Locality & $1 / \mathrm{L}$ & 3/B Diaph & 4/D Diaph & 5/B prox & 6/D prox & $\begin{array}{l}\text { 7/Dmag; } \\
\text { cun }\end{array}$ & 8/D unci \\
\hline \multirow{3}{*}{ MCIII } & Tagay & ca. 175 & $18.1 ; 22.1$ & $13.2 ; 13.9$ & 21.0 & ca.17 & 18.9 & $8.3 ; 8.5$ \\
\hline & Córcoles & $\begin{array}{c}163.2- \\
180.0\end{array}$ & $18.4-22.0$ & $14.0-16.4$ & $26.2-30.9$ & $19.0-22.2$ & $21.6-26.6$ & $6.0-8.3$ \\
\hline & Sansan & $\begin{array}{l}187.0- \\
207.5\end{array}$ & $20.0-25.0$ & $13.0-17.0$ & $26.5-30.2$ & $20.7-23.6$ & $21.9-28.0$ & $7.1-9.4$ \\
\hline \multirow{3}{*}{ MTIII } & Tagay & & 21.02 .15 & 16.3 & 25.8 & 22.4 & 25.6 & \\
\hline & Córcoles & & $18.6-21.2$ & $15.6-21.1$ & $28.6-34.4$ & $21.2-25.3$ & $27.2-33.0$ & \\
\hline & Sansan & & $19.9-26.1$ & $15.6-21.1$ & $28.6-34.4$ & $21.2-25.3$ & $27.2-33.0$ & \\
\hline \multirow{3}{*}{$\begin{array}{l}\text { Phalanx } \\
\text { II ant. }\end{array}$} & & $1 / \mathrm{L} \max$ & $2 / \mathrm{L}$ ant & 3/B Diaph & 4/B prox & 5/D prox & 6/B distal & \\
\hline & Tagay & 25.7 & 20.5 & 23.0 & 26.7 & 17.2 & 25.4 & \\
\hline & Córcoles & $22.8-26.8$ & $16.4-22.6$ & $24.9-31.9$ & $29.2-34.0$ & $16.0-18.8$ & $26.2-33.6$ & \\
\hline \multirow{4}{*}{ Tibia } & & 7/B distal & 8/D distal & Calcaneum & 3/B Diaph & 5/D tuber & & \\
\hline & Tagay & $38.5 ; 41.0$ & $30.2 ; 30.9$ & & $14.6 ; 13.0$ & 30.9 & & \\
\hline & Córcoles & $42.9-49.7$ & $30.8-35.4$ & & $12.2-16.2$ & $26.7-32.1$ & & \\
\hline & Sansan & $50.5-57.0$ & $34.0-38.7$ & & $13.6-20.0$ & $30.0-39.0$ & & \\
\hline \multirow{6}{*}{$\begin{array}{l}\text { Astra- } \\
\text { galus }\end{array}$} & & 1/L $\max$ & 2/D med & 3/B troch & 4/B max & 5/B dist & 6/D dist & 7/D prox \\
\hline & Tagay & $40.1-45.0$ & $37.0-42.8$ & $19.9-21.9$ & $37.9 ; 39.6$ & 31.7 & $21.3-25.0$ & $34.0-36.4$ \\
\hline & Córcoles & $39.6-46.0$ & $35.7-43.8$ & $18.8-23.8$ & $35.0-41.3$ & $28.2-32.3$ & $21.2-25.9$ & $30.8-37.0$ \\
\hline & $\begin{array}{l}\text { La } \\
\text { Romieu }\end{array}$ & 44.8 & 42.5 & 24.0 & 39.0 & 31.0 & 24.5 & 34.0 \\
\hline & Baigneaux & $40.0-48.3$ & $39.5-45.8$ & $20.0-25.5$ & $36.0-42.5$ & $29.1-34.2$ & $22.0-27.8$ & $28.5-38.4$ \\
\hline & Sansan & $40.0-45.0$ & $37.0-47.0$ & $21.0-27.0$ & $34.5-45.7$ & $29.7-43.1$ & $22.7-28.7$ & $30.6-39.8$ \\
\hline \multirow{3}{*}{$\begin{array}{l}\text { Phalanx } \\
\text { I post. }\end{array}$} & & $1 / \mathrm{L} \max$ & $2 / \mathrm{L}$ ant & 3/B Diaph & 4/B prox & 5/D prox & 7/D dist & 8/D dist \\
\hline & Tagay & 40.3 & 37.9 & 23.0 & 26.9 & 20.6 & 22.6 & 12.4 \\
\hline & Córcoles & $31.0-38.7$ & $25.4-34.2$ & $19.1-24.5$ & $25.5-30.6$ & $17.1-22.2$ & $23.9-27.9$ & $12.9-15.2$ \\
\hline \multirow{3}{*}{$\begin{array}{l}\text { Lateral } \\
\text { Phalanx } \\
\text { I }\end{array}$} & & $1 / \mathrm{L} \max$ & 2/B prox & 3/D prox & 4/B dist & 5/D dist & & \\
\hline & Tagay & 30.5 & 14.1 & 18.2 & 11.5 & 12.9 & & \\
\hline & Córcoles & $20.0-25.3$ & $9.2-13.0$ & $14.3-18.0$ & $8.4-11.6$ & $6.9-10.1$ & & \\
\hline
\end{tabular}

Table 4. Dental measurements and indices of Anchitherium aurelianense from Tagay (measuring system is according to Abusch-Siewert, 1983).

\begin{tabular}{|l|c|c|c|c|c|c|}
\hline & $\mathrm{L}$ & $\mathrm{Bh}$ & $\mathrm{Bm}$ & $\mathrm{Bv}$ & Hö Ms/Mc & Hö Pr \\
\hline P2 & 21.2 & 19.2 & 21.8 & 21.1 & 8.7 & 7.8 \\
\hline P3 & 20.2 & 23.4 & 24.8 & 23.3 & 9.7 & 8.9 \\
\hline P4 & 19.9 & 23.5 & 25.1 & 23.9 & 9.6 & 9.3 \\
\hline M1 & - & 22.9 & 23.3 & 22.5 & 8.1 & 8.3 \\
\hline M2 & 18.8 & 22.7 & 23.4 & 23.2 & 9.4 & 8.2 \\
\hline m3 & 19.5 & 9.0 & 9.1 & 10.4 & 7.6 & 7.1 \\
\hline
\end{tabular}

2 - HIL 50, HIB 36.6 \& 40.9, HIF 2.2, HIH 114.6. The scatterplot of length and maximum width of the upper premolars (Table 4., Fig. 3) show that the Tagay form values mainly project into the area of $A$. a. aurelianense and only slightly touch the areas of minimal values for A. a. steinheimense and A. a. hippoides. Therefore, though the Tagay anchithere is obviously specific in a peculiar combination of primitive characters, until a serial material on this form is available its attribution to one of the subspecies is premature.

The Tagay anchithere shows smaller teeth than A. corcolense from Early Miocene of Córcoles (Iñigo, 1997), though both forms are comparable in size of $\mathrm{P} 1$. These forms show very similar teeth morphology with poorly developed internal cingulum on premolars and its complete absence in molars, and in lacking crochet.
Teeth of anchithere from Belomechetskaya (attributed to A. aurelianense or Anchitherium sp.) are much larger (Borissiak, 1945; Gabunia, 1973) than even the large form from Gobi (Colbert, 1939). The single upper tooth from the Middle Miocene of Kalkaman (Kazakhstan) is morphologically very similar to the Tagay form. It shows metaloph connected to ectoloph, free protoloph, missing crochet, triangular hypostyle, anterior cingulum not connected with lingual one, but it is larger (Tleuberdina \& Forsten, 2001). The Gobi anchithere, Anchitherium gobiense Colbert, 1939, has basically very similar dental features to the Baikal form. At the same time the dental remains from Olkhon are considerably narrower than the Gobi anchithere from Northern China and Japan (Colbert, 1939; Ye et al., 2005). The features of the Gobi anchithere such as inflated 


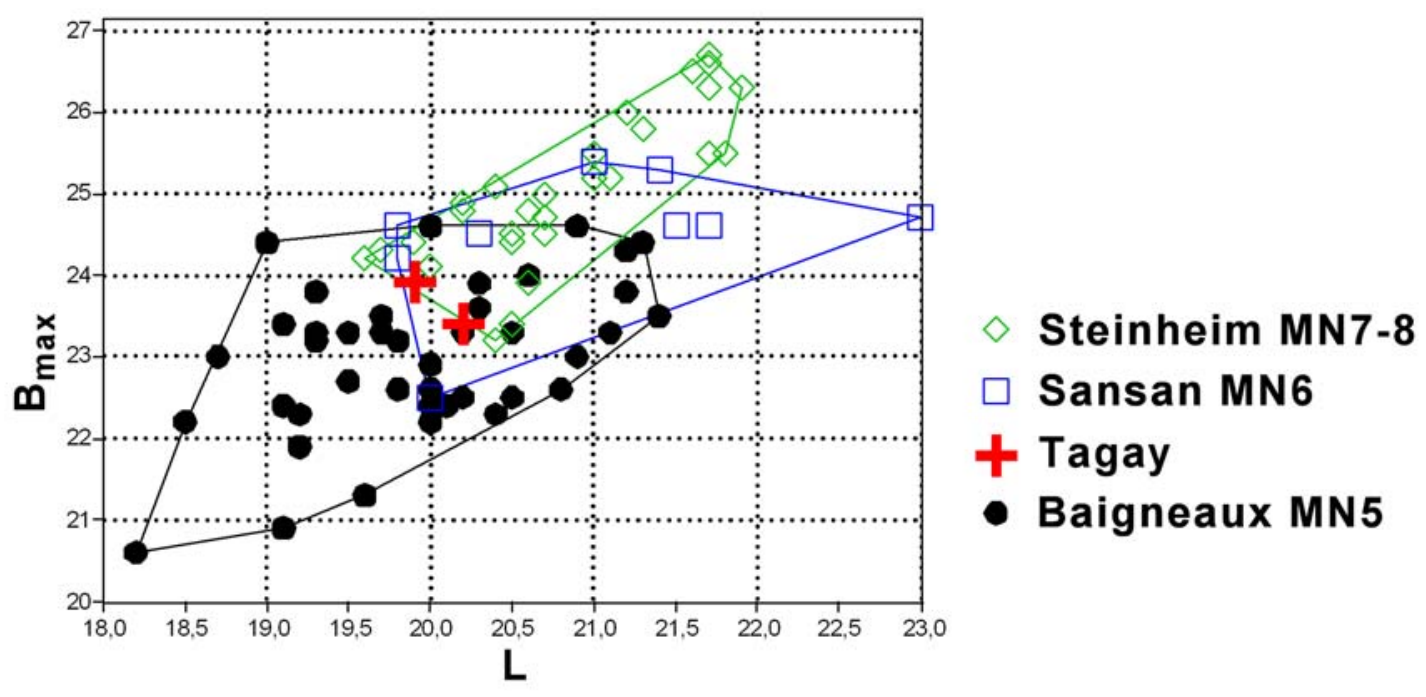

Fig. 3. Scatterplot of length (L) against maximum width (Bmax) of upper premolars P3/4 of Anchitherium aurelianense (Cuvier, 1825). Data for European forms is according to Abusch-Siewert (1983).

hypostyle and the absence of vertical ribs on ectoloph can be also observed in A. aurelianense from Sansan in Kovalevsky (1873, table III, figs. 52 and 53) and in the work of Alberdi \& Rodriguez, 2012, figs. 5-7). Largetoothed anchithere from Japan (Miyata \& Tomida, 2010) is slightly different from Tagay form in dental elements. It shows an incipient crochet and enamel cusplet at the mouth of the middle valley, in P2 hypocone is merged with hypostyle, and anterostyle appears. Tagay and Japanese forms very similar in connection of protoloph and paracone, hypostyle development in the rest of the upper molars, and shape of proto- and metaconule.

The Tagay form is distinct from Paranchiterium (Borissiak, 1945) in smaller dimensions, lack of crochet, and crown cement.

The Early-Middle Miocene Asian continental forms of $A$. aurelianense are mainly known from lower teeth (rarely, lower dentitions). Teeth from Kazakhstan anchitheres $(\mathrm{m} 1$ or $\mathrm{m} 2$ from a series of sites of different age) vary as $17.4 \times 12.2$ and $19.0 \times 12.0$; in Mongolian forms (Ulan-Tologoi), $16.6 \times 12.5 ; 15.9 \times 12.3 ; 16.5 \times$ 11.2; in Chinese forms (Fangxian), $18.9 \times 14.2 \mathrm{~mm}$ (Belyaeva, 1954; Miyata \& Tomida, 2010; Tleuberdina \& Forsten, 2001). Turkish forms from Paşalar show values $19.2-21.9 \times 14.6-17.6$ for premolars and 17.6$20.8 \times 15.5-15.7$ for molars (Forsten, 1990). The lower molar (m1 or $\mathrm{m} 2$ ) from Tagay (Fig. 1B) shows a degree of wear similar to the specimen PIN 3218-82 from Ulan Tologoi, but the Mongolian from is less robust and has the width index of $67.9 \%$. Lower molars from Kazakhstan sites in this respect are close to the Mongolian one (70.1 and 63.2\%). Chinese anchithere with the width index of $75.1 \%$ is similar to the form from Tagay. Turkish anchithere from Paşalar is very similar to the European forms (Forsten, 1990). The Tagay form is different from the Turkish equid in undifferentiated metaconid-metastylid complex and incomplete cingulum, but is similar in the weakly developed hypoconulid (index of width in Turkish form averages $72.2 \%$ ). Lower teeth of Anchitherium from Belomechetskaya (Gabunia, 1973) are very similar to material from Tagay. The North Caucasian form differs from the Mongolian and Gobi forms in closed internal valley of the lower molars. This character is though described based on a single specimen from each locality. The third lower molar from Tagay is more gracile than all specimens described from Kazakhstan (width index of 51.5 against 55.1, 55.9, and 60.1). It is close to East Asian forms (51.4 Gifu; 50.8 Fangxian; 50.0 Inner Mongolia; 50.7 Junggar Basin) (Tleuberdina \& Forsten, 2001; Miyata $\&$ Tomida, 2010). At the same time the Tagay specimen is quite small. It is narrower than all Asian form, and is only $14.7 \%$ longer than the specimen from Kumbulak (Kazakhstan).

The size and morphology of post-cranial skeleton of the European anchithere described by Kovalevsky (1873, 1948), Iñigo (1997), Alberdi \& Rodríguez (2012) are similar to Baikalian material. The difference is observed in the proportions of the distal limb bones. In Tagay form, antero-posterior dimensions of the metacarpal III and the pedal phalanx III-1, and their proximal width are less than in European anchitheres. At the same time the length of the manual phalanx III-2 in the Tagay form is notably larger. This bone also shows a strong narrowing of the lower epiphysis (Table 3 ). The lateral phalanx of the Tagay anchithere is also much larger. The unciform facet on the upper epiphysis of third metacarpal bone is well developed, especially in its anterior part. It is much larger than the facet for metacarpal II, which is is similar with the condition of A. corcolense. The development of the facet for metacarpal IV is unclear because lateral side of the bone is damaged. The astragalus of the Tagay form is lower 
and wider than in A. gobiense (Ye et al., 2005) with the width index 108.8 and 111.5 against 107.5. Cuneiforms III and II does not fuse similar to the condition described by Kovalevsky for the Sansan anchithere. It is thus similar to this bone from Córcoles (Iñigo, 1997). Structure of metacarpal III is similar to European anchitheres. Unfortunately, postcranial elements in Asian anchitheres are extremely poorly known, which hampers detailed comparisons.

The morphology of the distal parts of the extremities in the Tagay form indicates specific environment of the Olkhon area in the late Early Miocene. High values of the massiveness index of the astragalus (Córcoles, 112.63; Baigneaux, 114.54; La Romieu, 114.71\%) are characteristic of the all European anchitheres in Early Miocene (Alberdi \& Rodríguez, 2012). Narrow astragalus of the Gobi form (Ye et al., 2005) may point to open landscape habitats in Gobi. This conclusion is though tentative as it is based on a single record. The long first phalanx and large lateral phalanx in Tagay form may indicate habitats with wet grounds. The convex posterior part of the body of calcaneus, the protruding tuber of cuboid, rough plantar side of the first phalanx, small angle $\left(57^{\circ}\right)$ between the upper joint and the axis of the second phalanx (Gromova, 1949) collectively suggest a strong inclination of the toes to the ground in Tagay anchithere as another indication of soft grounds.

\section{Conclusions}

Based on strong similarity with the European materials, we refer the Tagay anchithere to the type species Anchitherium aurelianense (Cuvier, 1825). The temporal distribution of this species is restricted to the Early (Eurasia) and Middle (Europe) Miocene. The relative abundance of Anchitherium remains in Tagay assemblage indicates favourable conditions for its habitat. Basal dental morphology of Tagay form suggests an age older than Middle Miocene when the tooth morphology acquired distinctive derived features in the wide range of European and Asian forms. The morphology and dimensions of limb bones also point to attribution of the Tagay form to the early group within Anchitheriinae. Based on these data we refer the Tagay anchithere to Early Miocene. This age of the Tagay assemblage was also suggested on the basis of the study of artiodactyls (Vislobokova, 1990, 1994) and mylagaulid rodents (Tesakov \& Lopatin, 2015).

ACKNOWLEDGEMENTS. This work was supported by the Russian Foundation for Basic Research, program no. 14-04-00575. A.S.Tesakov (Geological Institute of the Russian Academy of Sciences, Moscow) helped to render the text in English. We are very grateful to the reviewers A.O. Averianov (St.-Petersburg), M.T. Alberdi (Madrid), and S. Mayda (Izmir) for critical comments. All members of the Tagay project are acknowledged for the high team spirit and collec- tive efforts which cumulatively brought fossil material described in this paper.

\section{References}

Abusch-Siewert S. 1983. Gebißmorphologische Untersuchungen an eurasiatischen Anchitherien (Equidae, Mammalia) unter besonderer Berucksichtigung der Fundstelle Sandelzhausen // Courier Forschungsinstitut Senckenberg. No.62. P.1-361.

Alberdi M. T., Ginsburg L. \& Rodríguez J. 2004. Anchitherium aurelianense (Mammalia, Equidae) (Cuvier, 1825) dans l'Orléanien (Miocène) de France // Geodiversitas. Vol.26. P.115-155.

Alberdi M.T. \& Rodríguez J. 2012. Anchitherium Meyer, 1844 (Perissodactyla, Equidae) de Sansan // Peigne S. \& Sen S. (eds.). Mammifères de Sansan. Muséum national d'Histoire naturelle. Paris. Mémoires du Muséum national d'Histoire naturelle. No.203. P.487-533.

Belyaeva E.I. 1954. [About finds anchitherium in Kazakhstan] // Trudy Paleontologicheskogo Instituta AN SSSR. Vol.47. P.55-60 [in Russian].

Borissiak A. 1945. [On the Equidae from the Middle Miocene of Northern Caucasus] // Trudy Paleontologicheskogo Instituta AN SSSR. Vol.13. No.1. P.1-52 [in Russian].

Bryant J.D. 2001. New Early Barstovian (Middle Miocene) Vertebrates from the Upper Torreya Formation, Eastern Florida Panhandle // Journal of Vertebrate Paleontology, Vol.11. No.4. P.472-489.

Colbert E.H. 1939. A New Anchitheriine horse from the Tung Gur Fomation of Mongolia // Amer. Mus. Novitates. No.1019. P.1-9.

Danilov I.G., Syromyatnikova E.V., Klementiev A.M., Sizov A.V., Martynovich N.V., Zelenkov N.V., Sychevskaya E.K. \& Tesakov A.S. 2012. [New data on the Miocene vertebrate location Tagay (Olkhon, Lake Baikal)] // Modern Paleontology: classical and new methods. Moscow: Paleontological Institute RAS. P.19-20 [in Russian].

Daxner-Höck G., Badamgaarav D., Erbajeva M. \& Göhlich U.B. 2013. Miocene Mammal Biostratigraphy of Central Mongolia (Valley of Lakes): new results // Wang X.-M., Flynn L.J. \& Fortelius M. (eds.). Fossil Mammals of Asia: Neogene Biostratigraphy and Chronology. New York: Columbia University Press. P.476-494.

Evander R.L. 2004. A revised dental nomenclature for fossil horses // Bulletin of the American Museum of Natural History. No.285. P.209-218.

Iñigo C. 1997. Anchitherium corcolense nov. sp., a new anchitherine (Equidae, Mammalia) from the Early Aragonian site of Córcoles (Guadalajara, Spain) // Geobios. Vol.30. No.6. P.849-869.

Ivanjev L.N. 1960. [Hipparion fauna of Transbaikalia and West Cisbaikalia] // Materials for the Conference on terrestrial zoogeography. Alma-Ata: Izdatel'stvo AN Kazakhskoi SSR. P.51-52 [in Russian].

Forsten A. 1990. Anchitherium from Paşalar, Turkey // Journal of Human Evolution. Vol.19. P.471-478. 
Forsten A. 1991. Size trends in holarctic Anchitherines (Mammalia, Equidae) // Journal of Paleontology Vol.65. No.1. P.147-159.

Gabunia L.K. 1973. [Belomechetskaya fauna of fossil vertebrates]. Tbilisi: Metsniireba. 147 p. [in Russian].

Gromova V.I. 1949. [History of horses (genus Equus) in the Old World, part 2] // Trudy Paleontologicheskogo Instituta AN SSSR. Vol.17. P.1-164 [in Russian].

Gromova V.I. 1952. [New discoveries of anchithere in Mongolia] // Trudy Paleontologicheskogo Instituta Akademii Nauk SSSR. Vol.41. P.87-98 [in Russian].

Hammer Ø., Harper D.A.T., Ryan P.D., 2001. PAST: Paleontological Statistics software package for education and data analysis // Palaeontologia Electronica. Vol.4. No.1. $9 \mathrm{p}$.

Kovalevsky W. 1873. Sur l'Anchitherium aurelianense Cuv. et sur l'Histoire Paléontologique des Chevaux // Mém. Acad. Imp. Sci. St.-Pétersbourg, 7 sér. Vol.20. No.5. P.1-73.

Kovalevsky W.O. 1948. [Paleontology of horses]. Moscow: Izdatel'stvo AN SSSR. 356 p. [in Russian].

Logachev N.A., Lomonosova T.K., Klimanova V.M. 1964 [The Cenozoic deposits of the Irkutsk Amphitheatre]. Moscow: Nauka Press. 196 p. [in Russian].

MacFadden B.J. 1998. Equidae // Janis C.M., Scott K.M., Louis L.J. (eds.). Evolution of Tertiary Mammals North America. Vol. 1. Cambridge: Cambridge University Press. P.537-559.

Mats V.D., Ufimtsev G.F., Mandelbaum M.M., Alakshin A.M., Pospeev A.V., Shimaraev M.N. \& Khlystov O.M. 2001. [Cenozoic of the Baikal Rift Zone]. Novosibirsk: Izdatel'stvo SO RAN, branch «GEO». 252 p. [in Russian].

Miyata K. \& Tomida Y. 2010 Anchitherium (Mammalia, Perissodactyla, Equidae) from the Early Miocene Hiramaki Formation, Gifu Prefecture, Japan, and its implica- tion for the early diversification of Asian Anchitherium // Journal of Paleontology. Vol.84. No.4. P.763-773.

Osborn H.F. 1918. Equidae of the Oligocene, Miocene and Pliocene of North America, iconographic type revision // Memoirs of the American Museum of Natural History, new ser. Vol.2. Part 1. P.1-331.

Stirton R.A. 1941. Development of characters in horse teeth and the dental nomenclature // Journal of Mammalogy. Vol.22. P.434-446.

Tesakov A.S. \& Lopatin A.V. 2015. First record of Mylagaulid rodents (Rodentia, Mammalia) from the Miocene of Eastern Siberia (Olkhon Island, Baikal Lake, Irkutsk Region, Russia) // Doklady Biological Sciences. Vol.460. P.23-26.

Tesakov A.S., Syromyatnikova E.V., Danilov I.G., Klementiev A.M., Sizov A.V., Zelenkov N.V., Sychevskaya E.K., Lopatin A.V., van den Hoek Ostende L.W., Martynovich N.V., Volkova N.V. \& Obraztsova E.M. 2014. [Progress in the study of Miocene vertebrates of Tagay (Olkhon Island, lake Baikal)] // Paleontology of Central Asia and adjacent regions: 45 years of the joint RussianMongolian Paleontological Expedition. Moscow: Paleontological Institute RAS. P.75-77 [in Russian].

Tleuberdina P. \& Forsten A. 2001. Anchitherium (Mammalia, Equidae) from Kazakhstan, Central Asia // Geobios. Vol.34. No.4. P.449-456.

Vislobokova I.A. 1990. [About artiodactyls from the Lower Miocene of the Tagay bay, Olkhon island (Baikal)] // Paleontological Journal AN SSSR. No.2. P.134-138 [in Russian].

Vislobokova I. 1994. The Lower Miocene artiodactyls of Tagay Bay, Olhon Island, Lake Baikal (Russia) // Palaeovertebrata. Vol.23. P.177-197.

Ye J., Wu W.Y. \& Meng J. 2005. Anchitherium from the Middle Miocene Halamagai Formation of Northern Junggar Basin, Xinjiang // Vertebrata PalAsiatica. Vol.43. No.2. P.100-109. 